\title{
A Role for Endoplasmic Reticulum Stress in Intracerebral Hemorrhage
}

\author{
Shaik Ismail Mohammed Thangameeran ${ }^{1,+}{ }^{\text {, Sheng-Tzung Tsai }}{ }^{1,2,3,+} \oplus$, Hsiang-Yi Hung ${ }^{2,3}$, \\ Wei-Fen Hu ${ }^{4}$, Cheng-Yoong Pang ${ }^{1,3,5,6}$, Shin-Yuan Chen ${ }^{1,2,3}$ and Hock-Kean Liew ${ }^{3,4,5,6, *}$ \\ 1 Institute of Medical Sciences, Tzu Chi University, Hualien 970, Taiwan; 106324122@gms.tcu.edu.tw (S.I.M.T.); \\ flydream.tsai@gmail.com (S.-T.T.); cypang@gms.tcu.edu.tw (C.-Y.P.); william.sychen@msa.hinet.net (S.-Y.C.) \\ 2 Department of Neurosurgery, Hualien Tzu Chi Hospital, Buddhist Tzu Chi Medical Foundation, \\ Hualien 970, Taiwan; shura0714@yahoo.com.tw \\ 3 Neuro-Medical Scientific Center, Hualien Tzu Chi Hospital, Buddhist Tzu Chi Medical Foundation, \\ Hualien 970, Taiwan \\ 4 PhD Program in Pharmacology and Toxicology, Tzu Chi University, Hualien 970, Taiwan; \\ 103327105@gms.tcu.edu.tw \\ 5 Department of Medical Research, Hualien Tzu Chi Hospital, Buddhist Tzu Chi Medical Foundation, \\ Hualie 970, Taiwan \\ 6 CardioVascular Research Center, Hualien Tzu Chi Hospital, Buddhist Tzu Chi Medical Foundation, \\ Hualien 970, Taiwan \\ * Correspondence: hockkean@tzuchi.com.tw or hockkean@hotmail.com; Tel.: +886-3-856-1825 (ext. 15911); \\ Fax: +886-3-8560-2019 \\ + These authors contributed equally to this paper.
}

Received: 14 February 2020; Accepted: 17 March 2020; Published: 19 March 2020

\begin{abstract}
The endoplasmic reticulum (ER) is an intracellular organelle that performs multiple functions, such as lipid biosynthesis, protein folding, and maintaining intracellular calcium homeostasis. Thus, conditions wherein the ER is unable to fold proteins is defined as ER stress, and an inbuilt quality control mechanism, called the unfolded protein response (UPR), is activated during ER stress, which serves as a recovery system that inhibits protein synthesis. Further, based on the severity of ER stress, the response could involve both proapoptotic and antiapoptotic phases. Intracerebral hemorrhage ( $\mathrm{ICH}$ ) is the second most common subtype of cerebral stroke and many lines of evidence have suggested a role for the ER in major neurological disorders. The injury mechanism during ICH includes hematoma formation, which in turn leads to inflammation, elevated intracranial pressure, and edema. a proper understanding of the injury mechanism(s) is required to effectively treat ICH and closing the gap between our current understanding of ER stress mechanisms and ICH injury can lead to valuable advances in the clinical management of ICH.
\end{abstract}

Keywords: intracerebral hemorrhage; ER stress; unfolded protein response; neuroinflammation; necroptosis; ferroptosis; pyroptosis

\section{Introduction}

Intracerebral hemorrhage (ICH) is a subtype of hemorrhagic stroke [1], morbidity, and mortality due to ICH is accounted depending on its location in the brain. Among all stroke subtypes, the proportion of ICH is different in various parts of the world; while in the USA, Europe, and Australia it accounts for only $10-15 \%$ of all strokes, surprisingly, this number can be as high as $20-30 \%$ among Asian populations [2]. ICH is also the second most common type of stroke in Taiwan, accounting for $16.1 \%$ of all strokes [3]. There are two stages of ICH-elicited injury, namely, primary brain injury (PBI) and secondary brain injury (SBI). PBI occurs due to the rupture of cerebral blood vessels predominantly 
because of cardiovascular conditions, with hypertension playing a major role. PBI is characterized by mechanical injury followed by a mass effect with the initial ictus causing physical tissue disruption that then leads to pathophysiological conditions in the brain.

A sudden rise in intracranial hematoma volume causes an increase in barotrauma and reduces blood flow to the area of the ictus [4,5]. Typically, PBI is followed by SBI, which is considered as a devastating stage after ICH, and the severity of SBI depends on the rate of recovery and location of the ICH. SBI involves the neuroinflammatory response to the triggering of the coagulation cascade through activation of the immune system. The inflammation size is based on the volume and position of the hematoma [5-7]. The various pathological factors responsible for SBI include the host immune response, release of thrombin, release of clot components (iron and heme), increased cytotoxicity, and inflammation [5,7]. The initial response to an ICH is the disruption of the blood-brain barrier, which causes the coagulation components to rush to the bleeding side, which involves the activation of microglia (the primary immune response cells; Figure 1) [8]. Activated microglia secrete numerous proinflammatory cytokines such as the tumor necrosis factor (TNF)- $\alpha$, interleukin (IL)-6, and IL-1 $\beta$ that ultimately lead to neuroinflammation [9], and these proinflammatory cytokines, when present at the injury site, tend to cause inflammation in situ [10]. Additionally, immediate lysis of red blood cells (RBCs) after ICH promotes the release of free hemoglobin, which is potentially neurotoxic, and it is degraded to heme and iron by an enzyme called heme oxygenase-1 (HO-1). Iron and heme toxicity play a vital role in SBI $[11,12]$. All these aforementioned pathophysiological stages, namely microglial activation, heme and iron release, can generate free radicals such as reactive oxygen species (ROS) and reactive nitrogen species, which can mediate neuroinflammation [6]. While the various mechanisms involved in neuroinflammation after ICH and associated modes of cell death are topics of interest, we have focused this review on understanding the role of ER stress in various cell death mechanisms after the initial ictus. 


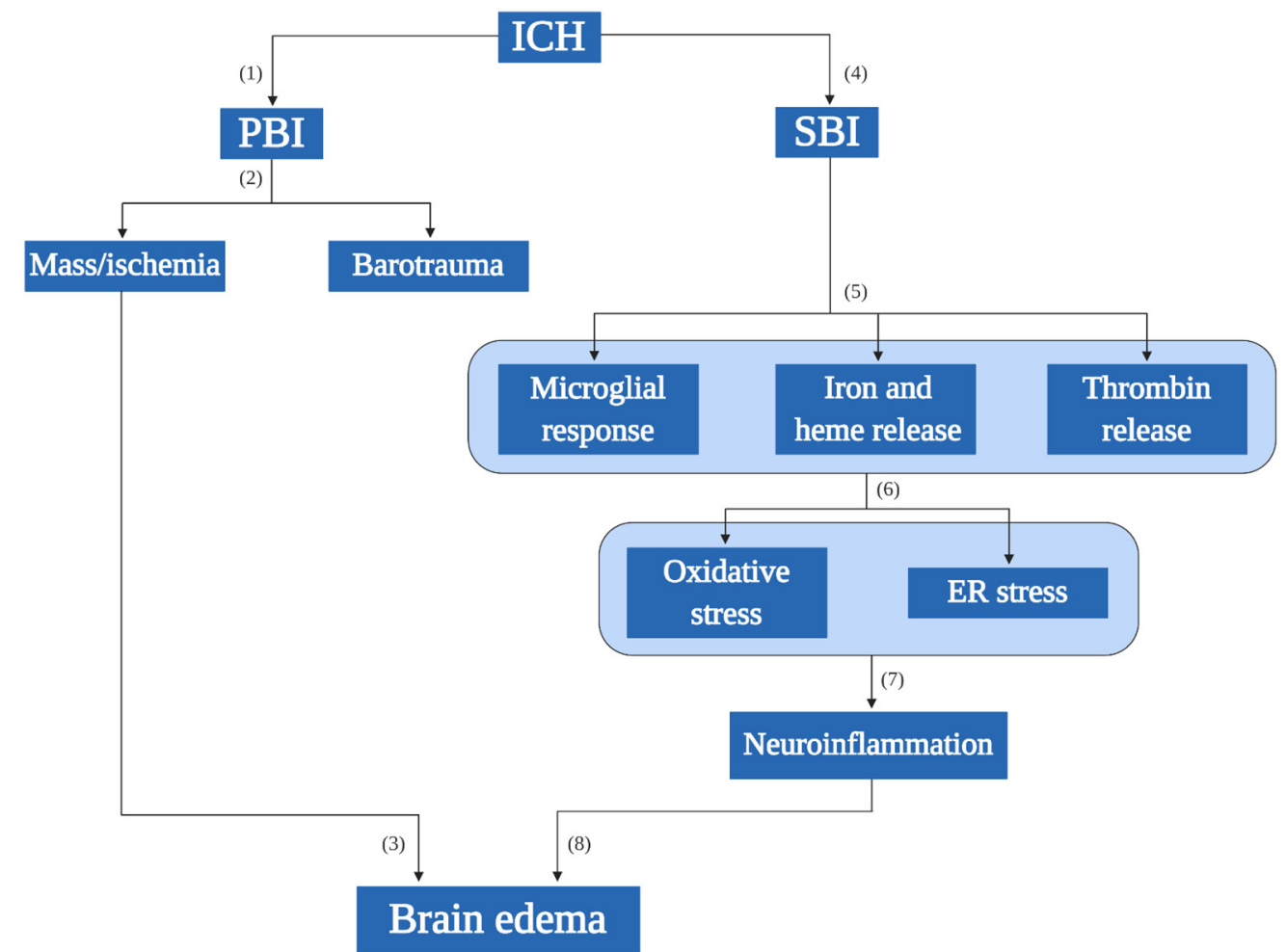

Figure 1. Pathology of intracerebral hemorrhage (ICH). Primary brain injury (PBI; 1 is the initial ictus that happens due to physical damage (2), which in turn leads to the mass effect or the ischemic effect that increases the volume of the hematoma (barotrauma). The mass/ischemic effect can directly influence the increase of the brain edema (3). The pathophysiology of $\mathrm{ICH}$ involves other series of steps called (4) the secondary brain injury (SBI, which is the long-term sequential aftereffects following ICH. The SBI events include (5) the release of thrombin, which acts as the initial response to repair the damaged site following which the host microglia come into play to engulf the erythrocytes. Since the initial ictus causes a clot in the site, there is an excessive release of clot components; majorly free iron and heme. (6) The course of events after SBI initiates the oxidative stress and ER stress consecutively contributing to (7) the neuroinflammation. (8) The progression of SBI events eventually leads to a brain edema. ICH: intracerebral hemorrhage, PBI: primary brain injury, SBI: secondary brain injury.

\section{General Therapeutic Interventions for ICH}

The initial screening for ICH uses imaging tools such as CT or MRI and this typically takes 3 days. This basic screening will also provide information on the location and volume of $\mathrm{ICH}$, and at the end of the first phase, physicians will be able to differentiate among $\mathrm{ICH}$, intraventricular hemorrhage, subarachnoid hemorrhage (SAH), ischemic stroke, primary brain tumors, and metastasis [13]. However, the subsequent procedure is CT angiography spot signs, even though this procedure helps identify active hemorrhage and understand the rate of ongoing bleeding its use is still under debate. Despite obvious advantages, the usage of $\mathrm{CT}$ angiography spot signs is not standard practice yet $[14,15]$. Following the first and second phase of diagnostics, the ICH score is evaluated to improve standard of the clinical management. This process involves assessing the Glasgow coma scale and other parameters that are necessary to arrive at an appropriate clinical management strategy [16].

Major factors taken into account during treatment strategy planning are age, neurological deficits, and blood pressure. Clinical management can include medical treatment for lowering blood pressure, coagulopathy, or even surgery (e.g., external ventricular drainage or hematoma evacuation; Figure 2) [17]. 


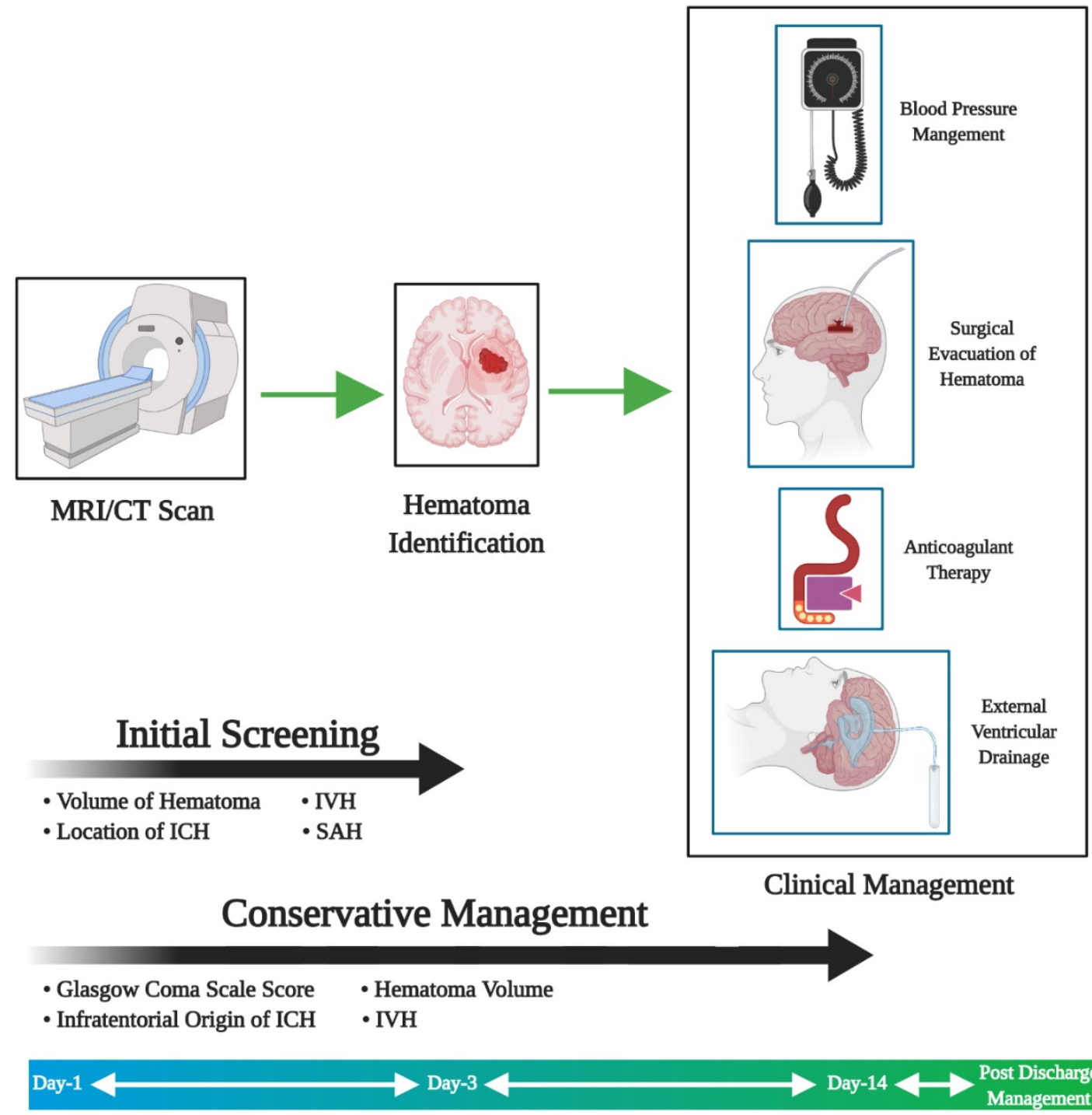

Figure 2. Clinical management of ICH. The steps involved in the clinical management of ICH are initial screening to analyze the clinical conditions followed by the screening procedure to understand the treatment needs of the patient. Based on the first three processes the clinical management is decided between surgical procedures or conservative management.

\section{Cell Death Pathways after ICH}

\subsection{Necrosis, Apoptosis, and Necroptosis}

Cell death after ICH is predominantly necrosis due to cellular disintegration; however, evidence of apoptosis has been documented in the form of DNA fragmentation using electrophoresis [18]. Additionally, a retrospective clinical study has suggested that apoptosis might be a major mechanism of cell death in ICH among human subjects in the perihematomal region [19]. Some studies have also investigated if a combination of both apoptosis and necrosis occurs after ICH in rat and rabbit models $[20,21]$. Necroptosis is programmed necrosis that occurs upon stimulation by proinflammatory cytokines, especially TNF- $\alpha$. The term 'Necroptosis' refers to a non-apoptotic cell death pathway and was coined by a study that focused on the role of a drug named necrostatin-1 (nec-1), which blocks the genetic determinant receptor-interacting serine/threonine-protein kinase 1 (RIPK1). Necroptosis induces inflammation, thereby slowing down the recovery process, and RIPK1 is responsible for inducing necroptosis in the cells treated with TNF- $\alpha$ [22]. Recent insights into the therapeutic efficacy of nec-1 
after ICH include its ability to inhibit TNF- $\alpha$-induced necroptosis to limit cell death and a reduction in hematoma volume in mice [23,24]. Interestingly, one study showed that either ferroptosis or necroptosis alone can sufficiently drive cells towards cell death pathways after ICH and that inhibition of either of these pathways can steer the neuronal cell towards survival [25]. While other unconventional cell death pathways like ferroptosis and pyroptosis have also been reported as possible mechanisms of ICH-induced cell death.

\subsection{Autophagy}

The exact mode of cell death after ICH remains unresolved; nonetheless, the three major morphologically distinct cell death pathways of necrosis, apoptosis, and autophagy are common in $\mathrm{ICH}$. The formation of autophagosomes requires the conversion of light chain-3 (LC3-I), which is cytosolic under normal conditions, to membrane bound LC3-II, and this conversion of LC3-1 to LC3-II is seen in ICH-induced rats. The existence of autophagy was determined by the morphology of the cells using electron microscopy and ICH rats showed an increased number of autophagic vacuoles in the perihematomal area, confirming a role for autophagy in $\mathrm{ICH}$-induced cell death. Furthermore, an iron chelator inhibited the LC3-I to LC3-II conversion, underscoring the importance of iron in ICH-induced autophagy in rats which underwent autologous blood infusion ICH surgery [26].

\subsection{Pyroptosis}

Pyroptosis has been recently gaining greater research attention as an important cell death pathway. It is different from apoptotic and autophagic cell death in that it requires inflammasomes and is mediated by caspase-1, i.e., it is a cysteine aspartate protease-dependent cell death pathway. The most common inflammasome sensors are absent in melanoma 2 (AIM2), and pyrin and nucleotide-binding oligomerization domain-like receptors (NLRs). The most prevalently studied inflammasome is NLR pyrin domain containing 3 (NLRP3) and it is thought to mediate various neurodegenerative and neurological disorders [22,27]. Pyroptosis involves the release of proinflammatory cytokines, especially IL-1 $\beta / \mathrm{IL}-18$; this, when combined with caspase- 1 and inflammasome activity, causes the cells to swell and burst, thus leading to cell death. Simultaneously, the released proinflammatory cytokines attract other immune cells, causing excessive inflammation. [28]. Caspase-1-dependent cell death has been documented after ICH, along with a role for P2X7 receptor-mediated pyroptotic cell death in hemorrhagic stroke [29]. Importantly, inhibition of caspase-1 by AC-YVAD-CMK (a selective inhibitor of caspase-1) reduced brain injury in a collagenase-induced mice model of ICH [29,30].

\subsection{Ferroptosis}

Ferroptosis is an iron-dependent form of non-apoptotic cell death. Activated microglia and infiltrating macrophages at the injury site engulf hemoglobin, degrade it, and release ferrous iron, which drives the production of ROS and results in lipid peroxidation; lipid peroxidation occurs when glutathione peroxidase 4 (GPX4) activity is inhibited. As there is excessive hemoglobin release after cell lysis in the post-ICH phase, the microglia accumulate surplus ferrous iron, which is transferred out of the microglia and accumulates in the neurons. This ferrous iron acts as the catalyst forming hydroxyl radicals through the Fenton reaction, and both hydroxyl radical and hydrogen peroxide are lethal ROS that elicit a neuroinflammatory response. The excessive release of hemoglobin after ICH due to erythrocyte lysis further increases ferroptosis post-ICH. a role for ferroptosis in $\mathrm{ICH}$ was demonstrated by inhibiting it using a specific inhibitor, ferrostatin-1, to rescue neuronal cell death due to excessive iron deposition. Interestingly ferrostatin-1 was able to reduce neuronal death by inhibiting lipid ROS and cyclooxygenase (COX)-2 expression [31,32]. Figure 3 provides the illustrated form of cell death pathways after ICH. 


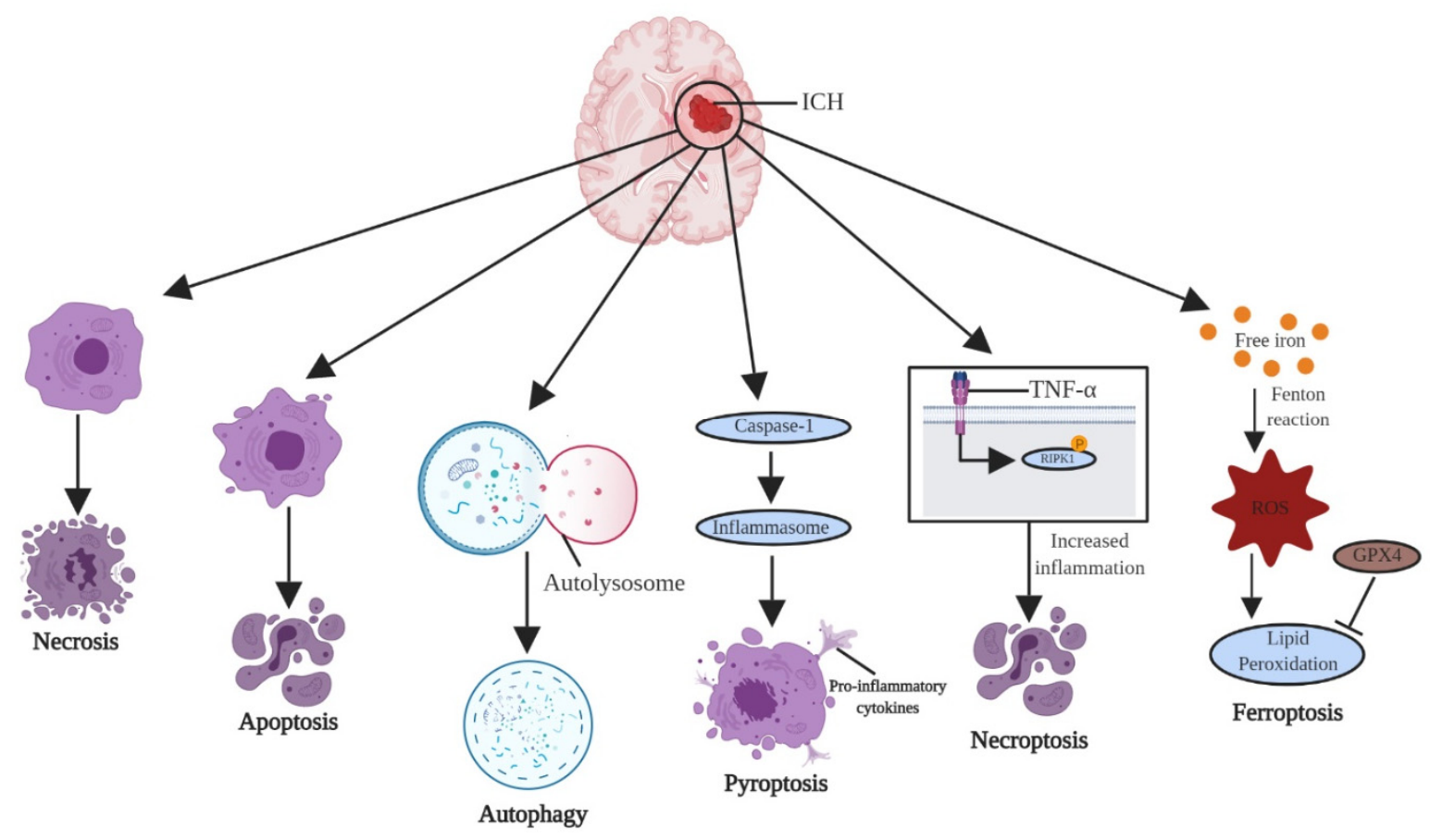

Figure 3. Cell death pathways in ICH. ICH includes all the three conventional forms of cell death (necrosis, apoptosis, and autophagy). Apart from regular cell death pathway, ICH also involves pyroptosis, necroptosis, and ferroptosis.

\section{Endoplasmic Reticulum Stress}

ER is an integral organelle found in all eukaryotic cells and its vital functions include ensuring uninterrupted protein folding, synthesis of unsaturated fatty acids, and maintenance of intracellular $\mathrm{Ca}^{2+}$ homeostasis. Protein synthesis requires integration of the ER with the ribosome [33], and chaperones come into play to complete protein synthesis [34]. Various factors can perturb the normal function of the ER and cause ER stress, and these factors include hypoxia, hypoglycemia, hyperthermia, and improper calcium homeostasis [35]. Under stress conditions, the ER encounters aggregation of misfolded and unfolded proteins, which then elicits the UPR. The primary role of UPR is to restore normal function of the ER. Notably, cell death ensues if ER function cannot be restored, and the severity of ER stress determines whether cell death occurs through caspase-dependent or caspase-independent pathways [36]. The ER stress signal is primarily initiated by three effector proteins, the protein kinase RNA-like endoplasmic reticulum kinase (PERK), inositol-requiring protein-1 (IRE1), and activating transcription factor-6 (ATF6). These three transmembrane protein sensors are responsible for restoring homeostasis during UPR and are held in an inactive state by the binding immunoglobulin protein (BiP), also known as glucose regulated protein 78 (GRP78), which is a member of the heat shock protein-70 (hsp70) family. Normally, BiP is bound to the three effector proteins, but during ER stress or $\mathrm{UPR}, \mathrm{BiP}$ disassociates from the effector proteins, which leads to sequential activation of downstream effector proteins. Illustrated form of UPR molecular pathways is given in Figure 4. 


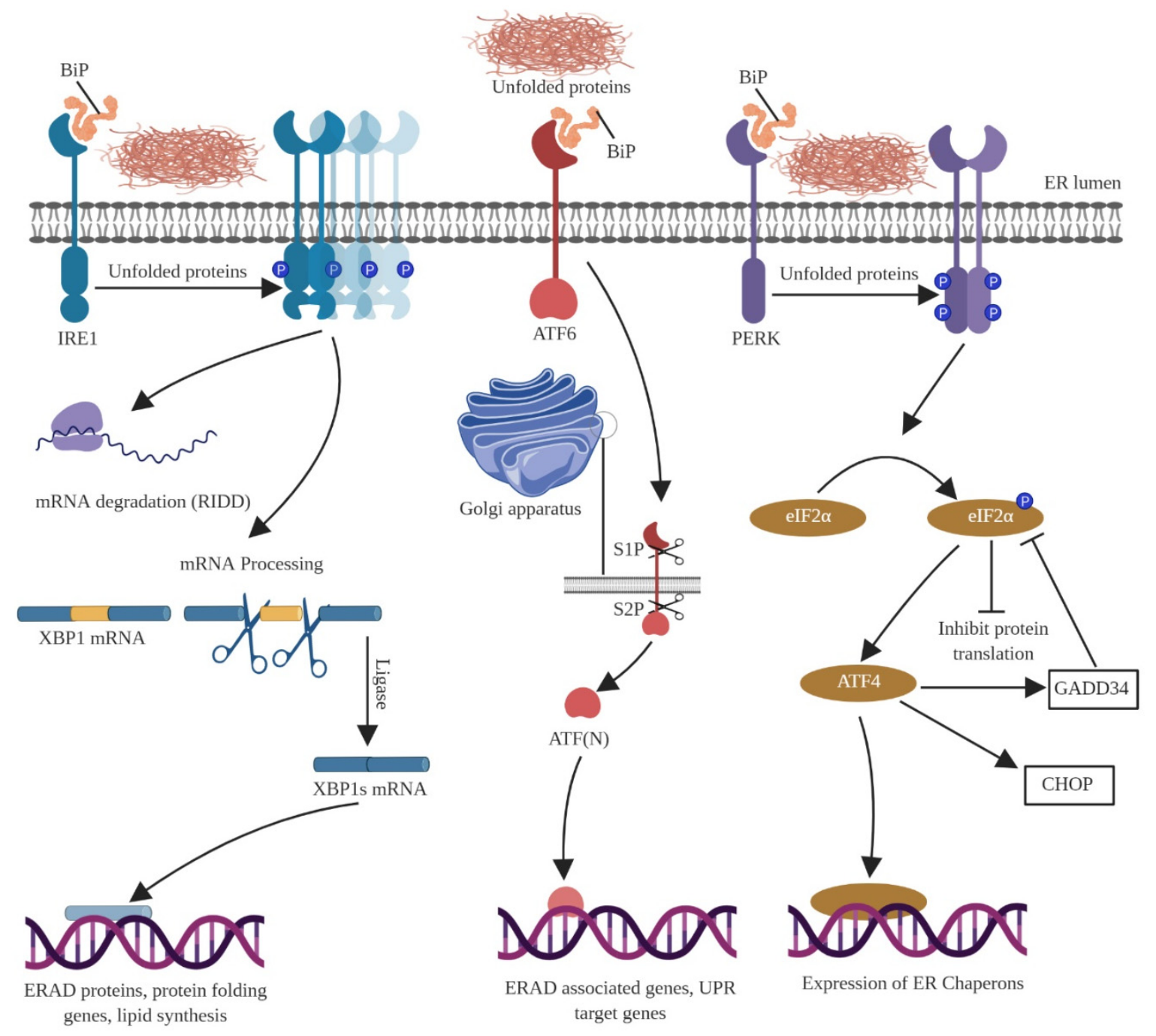

Figure 4. The molecular pathways of the unfolded protein response (UPR. During ER stress the three ER transducers (IRE1, PERK, and ATF6) tend to get activated and start the UPR mechanism to counteract the ER stress and to bring back the homeostasis. Failure to negate the ER stress will result in cell death. IRE1 undergoes oligomerization in response to unfolded proteins and the BiP gets dissociated from IRE1. IRE1 undergoes either mRNA degradation or mRNA processing with the help of XBP-1, which triggers the production of protein folding genes thereby mitigating ER stress. On the other hand, ATF6 gets into the secretory pathway inside the Golgi apparatus wherein the S1P and S2P cleave the ATF6. ATF6 fragments then translocate into the nucleus, which act as a transcription factor to generate UPR target genes. PERK first phosphorylates itself and also phosphorylates eIF $2 \alpha$ thereby inactivating eIF2B, which further inhibits the translation of serine 51. This process leads to the translation of ATF4 producing ER chaperones.

The two main functions of the three effector proteins in their active state are to cease protein synthesis to reduce ER stress and to increase the transcriptional activation of genes responsible for efficient protein folding [37]. The critical role(s) played by cell death signaling pathways involving ER transducers during the UPR has been a major area of research in the fields of neurodegenerative diseases, diabetes, and heart, kidney, and liver diseases [38]. Understanding all components of the UPR will provide greater insight about its activation or deactivation, which might be beneficial in the treatment of ICH. Thus, the arguments in favor of connecting the dots to understand the exact function of ER stress in inducing cell death post-ICH are compelling. 


\section{Molecular Pathways of ER Stress}

\subsection{ER Transducer-Inositol-Requiring Protein-1 (IRE1)}

IRE1 is a type-1 ER transmembrane protein with an inner N-terminal luminal domain, a cytoplasmic domain, and an RNase domain. Normally, chaperones such as BiP bind to and prevent activation of IRE1; however, during ER stress, BiP disassociates from IRE1 and actively participates in the UPR. During UPR, the luminal domain of the IRE1 dissociates, which induces transautophosphorylation and conformational change of IRE1 that in turn activates its RNase domain. Activated IRE1 involves in the unconditional splicing of the mRNA of the transcription factor X-box binding protein-1 (XBP1), which further promotes the XBP1 dependent gene expression program. There are studies in yeast and mammalian cells that show the direct association of unfolded proteins with IRE1. The unfolded proteins directly bind with the luminal domain of IRE1. This association between unfolded proteins and IRE1 causes conformational change and oligomerization of IRE1 [39-45]. Data from Caenorhabditis elegans and mouse models demonstrate that, during UPR, IRE1-dependent downstream signaling is activated by splicing of mRNA that encodes XBP1 [46]. IRE1 is part of an inherent mechanism known as the regulated IRE1-dependent decay (RIDD), which has diverse effects on the cell that can lead to either preservation of homeostasis or cell death $[47,48]$.

\subsection{ER Transducer-Activating Transcription Factor 6 (ATF6)}

As the name suggests, ATF6 is a transcription factor of the leucine zipper family that is localized to the ER and has a molecular weight of $50 \mathrm{kDa}$ in its activated form. During ER stress, BiP dissociates from ATF6, which results in the exposure of its Golgi localization sequence [49]; ATF6 is then processed by Site-I (S1P) and Site-II (S2P) proteases followed by the release of ATF6 fragments [50]. These released ATF6 fragments enter the nucleus and induce promoters of the grp genes by activating the ER-stress-response elements [51]. Mammals exhibit two homologous ATF6 proteins, namely ATF6 $\alpha$ and ATF6 $\beta$ [52], and grp genes are regulated by AFT6 $\alpha$ after it enters the nucleus during ER stress. The functional importance of ATF6 $\beta$ remains less understood. ATF6 $\alpha$ also plays a major role in inducing the nuclear expression of chaperones BiP and Xbp1 [53]. ATF6 $\alpha$-assisted induction of UPR mediators and chaperones is considered to be the prime switch that downregulates IRE1 signaling [54].

\subsection{ER Transducer-Protein Kinase R-Like Endoplasmic Reticulum Kinase (PERK)}

PERK is a type-I transmembrane protein, and as its translational role was first established using pancreatic cells, it is called pancreatic ER kinase or protein kinase RNA-like ER kinase [55]. PERK shares an identical domain assembly with IRE1 [56] and it is an ER-resident transmembrane kinase. The UPR activation is a mechanism to restore homeostasis through promoting protein folding via chaperones, degrading misfolded proteins, or slowing translation. This reduces the load of unfolded proteins and increases the efficiency of protein folding. While IRE1 and ATF6 activate genes responsible for mitigating protein folding capacity [57], unfolded protein load is controlled by PERK. The absence of PERK leads to excessive protein synthesis, which ultimately results in extreme ER stress and disruption of cell homeostasis ultimately resulting in cell death [58]. Under normal conditions, BiP is found attached to the luminal domain of the PERK protein; however, during ER stress, BiP disassociates from the luminal domain and helps lessen the increasing protein load [56]. Like IRE1, PERK also has a direct relationship between misfolded proteins and its oligomerization, which triggers the UPR [59]. PERK phosphorylates eukaryotic translation initiation factor $2 \alpha(\mathrm{eIF} 2 \alpha)$ on serine 51 and this phosphorylation inhibits eIF2B, ensuring the translation of ATF4. The translation of ATF-4 induces the CHOP genes and the growth arrest and DNA damage-inducible 34 (GADD34) genes. The former acts as a transcription factor that is responsible for apoptosis and the latter is a negative regulator that stops the UPR by dephosphorylating eIF2 $\alpha$ with the help of protein phosphatase 1 (PP1c), thereby restarting the protein synthesis process $[60,61]$. 


\subsection{Calcium Homeostasis and ER Stress}

Apart from protein and lipid biosynthesis, the ER also serves as an essential $\mathrm{Ca}^{2+}$ storage site in eukaryotic cells. $\mathrm{Ca}^{2+}$ homeostasis is necessary for normal functioning of the cell and three main processes contribute to maintaining $\mathrm{Ca}^{2+}$ equilibrium in the ER. These are (i) ensuring that the $\mathrm{Ca}^{2+}$ store within the ER lumen is replenished from the cytosol; (ii) maintaining $\mathrm{Ca}^{2+}$ within the ER using binding proteins; and (iii) controlled release of calcium from the ER to the cytosol [62]. Thus, ER Ca ${ }^{2+}$ equilibrium is maintained by controlling the influx and the outflow of $\mathrm{Ca}^{2+}$. The main $\mathrm{Ca}^{2+}$ release machinery is regulated by ryanodine-receptor (RyR) and inositol 1,4,5-trisphosphate (IP3) receptor (IP3R) $[63,64]$. Upon binding to specific ligands $\left(\mathrm{Ca}^{2+}\right.$ for RyR and IP3 for IP3R), RyR and IP3R tend to release $\mathrm{Ca}^{2+}$ from the ER, which reduces $\mathrm{Ca}^{2+}$ concentration within the ER [65]. This process is followed by replenishment of $\mathrm{ER} \mathrm{Ca}^{2+}$ from extracellular sources through the plasma membrane; this is executed by store operated $\mathrm{Ca}^{2+}$ entry (SOCE) through calcium release-activated calcium channels. SOCE is modulated by the ER membrane protein stromal interaction molecule 1 and 2 (STIM1/2) and plasma membrane protein calcium release-activated calcium channel protein 1 (ORAI1) [66,67].

The oligomerization of STIM1/2 and ORAI1 proteins is the primary mechanism that restores ER $\mathrm{Ca}^{2+}$ levels, and recent insights into ER $\mathrm{Ca}^{2+}$ reduction show an association with ER stress $[68,69]$. $\mathrm{Ca}^{2+}$ homeostasis in the ER is essential because of $\mathrm{Ca}^{2+}$-dependent folding of newly synthesized proteins [70,71]; specifically, any decrease in the ER $\mathrm{Ca}^{2+}$ disrupts the function of GRP78/BiP and other chaperones, which causes the accumulation of unfolded proteins. Hence, when the ER transducers experience a lack of GRP78/BiP, they activate the transducers and promote the early or late response to unfolded proteins in the ER [72]. The importance of the various components of the SOCE machinery has been demonstrated in many disease conditions. In a rat model of ischemic stroke due to transient middle cerebral artery occlusion, STIM1/ORAI1 have shown to play a role in restoring neurological function [73]. This STIM1-ORAI1 interaction has also been shown to be functionally important in a cat model of hypertrophy-related calcium dysfunction in myocytes [74]. Similarly, Stim1 silencing by in vivo gene delivery of shRNAs, impairs the adaptive response to hypertrophy, which results in heart failure [75]. The critical effects of STIM1 and ORAI1 are seen in platelets during pathological thrombus formation [76,77] wherein STIM1 mediates the procoagulant activity and ORIA1 involves in platelet activation. Apart from STIM1, STIM2 has also been shown to be essential for regulating capacitive $\mathrm{Ca}^{2+}$ in neurons, apart from inducing hypoxic neuronal cell death [78]. Although the role of SOCE and its components (STIM1/2 and ORAI1) has been a major area of research focus in recent years, there is little or no evidence that links the SOCE machinery with ICH. Therefore, in the following sections, an attempt has been made to connect ER stress and cell death pathways in ICH.

\section{Crosslinking ER Stress and ICH-Related Cell Death Pathways}

ICH disrupts cell metabolism and it is shown to activate a series of stress responses including ER stress [79]. On the other hand, ER dysfunction caused by protein misfolding and oxidative stress has led to acute central nervous system damage [80,81]. Recently, we have elucidated that acute phase of ICH has exacerbated the ER stress through proteasome overactivation, which also lead to neuroinflammation [82]. Although the studies to describe the relationship between ER stress and ICH are minimal, it is necessary to analyze the role of ER stress in ICH because of the crucial interplay between ER stress and various other factors involved in $\mathrm{ICH}$ pathophysiology including microglial activation, oxidative stress, neuroinflammation, and heme release [83-85]. An analysis of the function of ER stress components and their relationship with different ICH cell death pathways (apoptosis, autophagy, pyroptosis, necroptosis, and ferroptosis) will provide deeper insight into the critical contribution(s) of ER stress in post-ICH damage (Figures 5 and 6). 


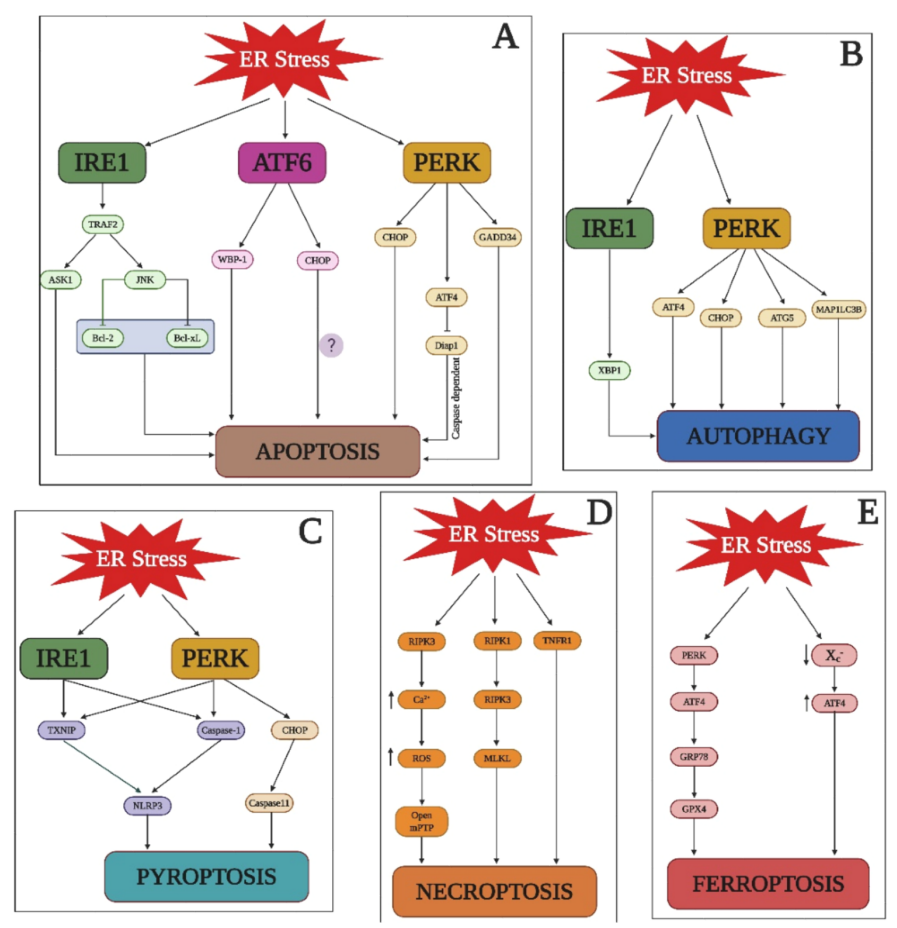

Figure 5. ER stress and cell death. a depiction of ER stress related signal transduction pathways that is responsible for apoptosis, autophagy, pyroptosis, necroptosis, and ferroptosis.

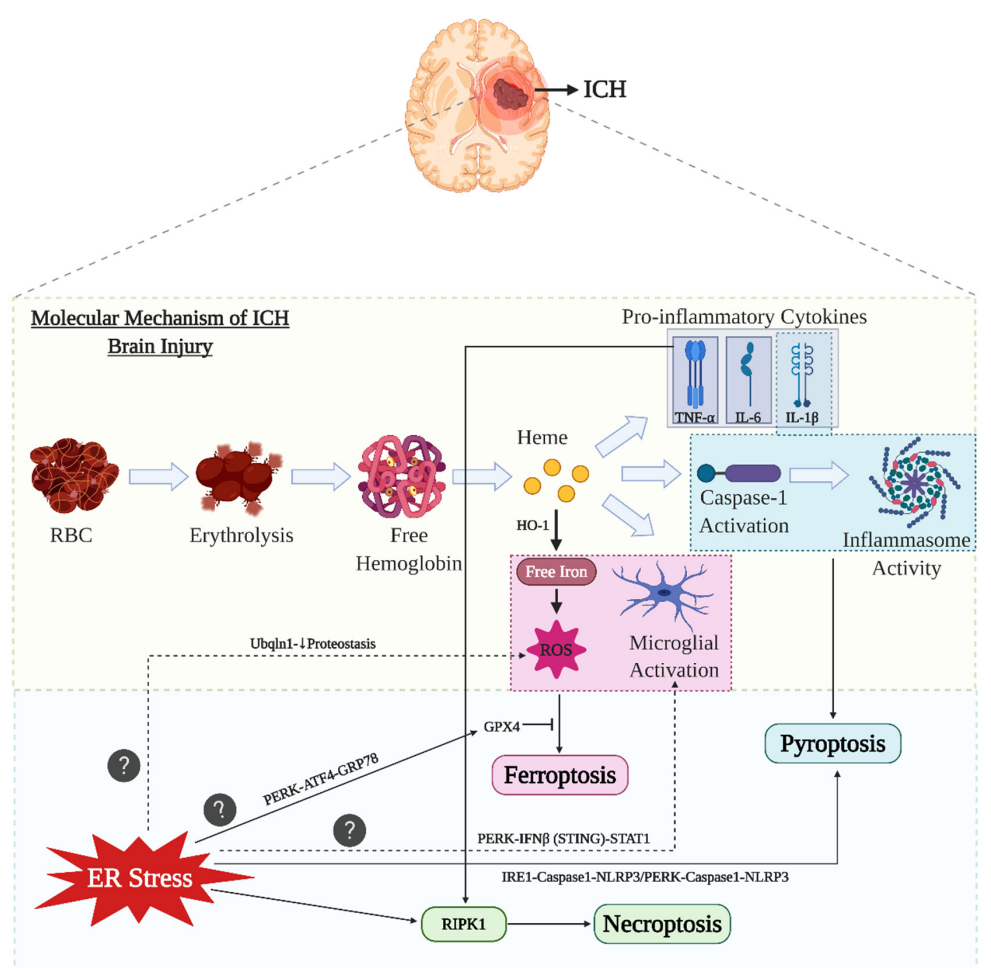

Figure 6. ER stress and ICH-related cell death pathways. The molecular mechanisms involved after ICH namely microglial activation and ROS production directly leads to ferroptosis by inhibiting GPX4. 
The role for ER stress to actively participate in ferroptosis is still a question. However, the role of ER stress is demonstrated to mediate GPX4 through its PERK arm. The caspase- 1 activation and inflammasome activities after ICH leads to pyroptosis. The interrelation of the ER stress with pyroptosis involves both the IRE1 and PERK arms. The proinflammatory cytokine release responsible for neuroinflammation activates RIPK1 to further induce necroptosis. There is evidence that ER stress directly activating RIPK1 thereby causing necroptosis. However, the direct relationship with all these three ICH cell death pathways with that or ER stress is still not elucidated. However, future studies should be focused on these three unconventional ICH related cell death pathways wherein ER stress plays a key role. The role of proteostasis and PERK arm is also further explained to have a relationship with oxidative stress and microglial activation.

\subsection{ER Stress in Apoptosis}

The ER transducers, IRE1, ATF6, and PERK, not only mediate ER stress but can also trigger proapoptotic signaling. This process occurs indirectly through downstream signaling molecules. The ER transducers are critical for ensuring homeostasis within a cell during ER stress and their effects are solely dependent on the intensity of the stress. For, e.g., in the context of prolonged ER stress, the prosurvival activity of the ER transducers switches to proapoptotic signaling, and PERK is responsible for attenuating the UPR [58]. The downstream translation of ATF4 from the PERK arm plays a role in both prosurvival and proapoptotic pathways during ER stress because it not only induces genes responsible for amino acid metabolism, protein secretion, and redox reactions, but also activates $\mathrm{CHOP}$, which is responsible for promoting apoptotic cell death. On the other hand, under mild stress, PERK is important for ensuring pro-survival activities. However, the overexpression of other target genes, such as GADD34 from the PERK pathway, can also result in apoptosis.

An independent role for ATF4 in caspase-mediated apoptosis was demonstrated in a new drosophila model of chronic ER stress $[53,61,86,87]$. ATF6 has also been shown to induce CHOP but its relevance to the proapoptotic pathway is not well demonstrated; nonetheless, its relevance to apoptosis has been documented in myoblast cells wherein overexpression of ATF6 induced apoptosis by upregulating the WW domain binding protein (WBP)-1 [88]. Additionally, ATF6 plays a key role in apoptosis as the knockdown of ATF6 resulted in decreased apoptosis in mouse granulosa cells [89]. IRE1, on the other hand, has been shown to be involved in proapoptotic signaling and the activation of kinase pathways. During ER stress, IRE1 activates the c-Jun amino-terminal kinase (JNK) with the help of an adaptor protein called tumor necrosis factor receptor (TNFR)-associated factor-2 (TRAF2) [90]. This IRE1-TRAF2 complex in turn activates the apoptosis-signal-regulating kinase (ASK)-1 [91]; overactivation of ASK1 has been demonstrated during apoptosis of various cell types, especially neurons [92,93]. JNK, on the other hand, can also inhibit the anti-apoptotic activity of B-cell lymphoma (BCL)-2 and B-cell lymphoma-extra-large (Bcl-XL) by phosphorylating (BCL)-2 [94,95].

\subsection{ER Stress in Autophagy}

Autophagy is a prosurvival response to ER stress in many conditions and is essential for removing misfolded proteins [96]. The induction of autophagy by ER stress has been shown to be both beneficial and detrimental for the cells. When cells are exposed to hypoxic conditions, there is an increase in ER stress, which induces autophagy in an ATF4-dependent manner, thus extending our understanding into the mechanistic link between the UPR and autophagy [97]. The relationship between PERK and autophagy has been described in human cancer cells lines wherein hypoxia increased the transcription of genes that are important for autophagy, namely microtubule-associated protein 1 light chain $3 \beta$ (MAP1LC3B) and autophagy-related gene 5 (ATG5); the latter represents the association between the PERK arm of the UPR system after ER stress and hypoxia-induced autophagy [98]. The downstream regulators of the PERK arm (ATF4 and CHOP) have been shown to increase the transcription of autophagy genes [99]. UPR branches and their downstream proteins play a major role in autophagy but they may either induce or inhibit it as the proteins downstream of IRE1 (XBP1) promote both 
induction and inhibition of autophagy. Specifically, the PERK downstream protein (ATF4) and the ATF6 arm of the UPR induce autophagy [100].

\subsection{ER Stress in Pyroptosis}

Recent research has demonstrated a relationship between ER stress and inflammasome activation in various pathologies. One study in a rat model of spinal cord injury has described that the thioredoxin interacting protein (TXNIP) - a protein induced by ER stress-activates NLRP3 inflammasomes. However, that study did not clarify the relevant molecular pathways between inflammasome and ER stress [101], but earlier studies have shown the importance of TXNIP in inflammasome pathways during ER stress [102,103]. Pyroptosis occurred due to the involvement of TXNIP with PERK and IRE1 $\alpha$, which induced IL-1 $\beta$ mRNA transcription and IL-1 $\beta$ production with the help of the NLRP3 inflammasome [104]. Another study in a hepatocyte model demonstrated that ER stress led to NLRP3 inflammasome activation by PERK and IRE1 $\alpha$, which resulted in the overexpression of caspase- 1 and led to pyroptosis [105]. In an ischemia-reperfusion-induced acute kidney injury model, ER stress activated the CHOP-caspase-11 pathway, thereby inducing pyroptosis of the renal tubule epithelial cells [106]. a role for ER stress in the activation of inflammasomes and IL-1 $\beta$ production has been reported to be pivotal in liver damage and steatosis [107].

\subsection{ER Stress in Necroptosis}

ER-stress-induced necroptosis has been shown by multiple studies. In a mouse model of cardiac ischemia-reperfusion (IR) injury, the RIPK family of proteins (RIPK3) stimulated ER stress and mediated necroptosis. The underlying signal transduction pathway consisted of an increase in calcium in the ER following an increase in ROS; this opened the mitochondrial permeability transition pore (mPTP), causing necroptosis of the cardiomyocytes. Additionally, overexpression of ER stress markers (GRP78, CHOP, and PERK) was observed in the cardiomyocytes of IR mice compared to RIPK3 knockout mice [108]. Another study aimed to elucidate the role of ER stress in inducing necroptosis through the RIPK1/RIPK3/mixed lineage kinase domain-like protein (MLKL)-dependent pathway in L929 cells and demonstrated that necroptosis was indeed TNFR1 dependent [109].

\subsection{ER Stress in Ferroptosis}

A possible relationship between ER stress and ferroptosis was unraveled in a glioma model, wherein the PERK-ATF4-GRP78 pathway inhibits GPX4, which in turn modulates ferroptosis. Interestingly, the inhibition of ER stress enhanced ferroptosis and complemented the anticancer activity of dihydroartemisinin [110]. Although a direct relationship between ER stress and ferroptosis has not yet been established, it is known that the inhibition of cystine/glutamate transporter (xc-) increases ER stress by upregulating ATF4, and that it also increases ferroptosis in cancer cell lines [111].

\section{ER Stress Components and ICH Therapeutic Strategies}

By understanding the relationship between ER stress in either activation of inhibition of other prominent factors of ICH including microglial activation [5,9], ROS production [6], proinflammatory cytokine release [11], and heme and iron release [13,14]; we will have a greater knowledge on the molecular mechanism involved in ICH induced secondary brain injury. In a traumatic brain injury (TBI) model, increased PERK phosphorylation resulted in the excessive release of interferon (IFN)- $\beta$ through stimulator of interferon gene (STING) signaling pathway. IFN- $\beta$, in turn, causes microglial activation via STAT1 signaling pathway and the release of proinflammatory cytokines. The study also demonstrated that blocking PERK-phosphorylation by either GSK2656157 or PERK knockdown prevents the activation of microglia [112].

Apart from microglial activation, another important factor in ICH-induced neuroinflammation is oxidative stress. The interrelation between proteostasis and oxidative stress was demonstrated in the ischemic stroke mouse model: administration of L-2-oxothiazolidine-4-carboxylic acid 
(OTC), a precursor of cysteine, upregulates ubiquilin-1 (Ubqln1) and enhances proteostasis and glutathione (GSH) level. GSH is an important antioxidant synthesized in cells, which detoxifies ROS. However, the therapeutic effect of OTC diminishes in Ubqln1 knockout mice after cerebral stroke, suggesting that the therapeutic potential of OTC involves both antioxidative property and proteostasis enhancement [113]. Another study from the same group also demonstrated that the administration of nialamide (a non-selective monoamine oxidase inhibitor) in the ischemic stroke mouse model can also upregulate Ubqln1, and in turn reduces oxidative stress as well as neuroinflammation (Figure 6) [114].

The activities of the three ER transducers in promoting UPR represent an ideal target for mitigating ER stress, but if the sensors are activated for prolonged periods of time, the UPR mechanism turns detrimental in all cell types, including neuronal cells. Protein translation overload is temporarily halted by PERK; hence, the function of PERK is extremely important for easing the UPR. PERK is functionally essential for deciding neuronal fate because it is a crucial mediator of ER stress [115], and numerous pharmacological agents are capable of targeting the UPR and ER stress components. Thus, existing approaches to treat ICH can be combined with pharmacological agents that can directly activate or deactivate ER stress components, which might play a critical role in alleviating post-ICH symptoms.

The PERK/eIF2 $\alpha$ pathway and its downstream regulators have been shown to be upregulated in studies related to cerebral ischemia [116], recurrent febrile seizures [117], and traumatic brain injury [118], and the involvement of PERK has been previously documented in a brain ischemia and reperfusion model, with the help of eIF2 $\alpha$. [119]. In an autologous blood infusion model of ICH, PERK was upregulated with the help of phosphorylated-eIF2 $\alpha$ and ATF4. Due to RBC lysis and free hemoglobin release, heme exposure is prevalent in the perihematomal area after ICH [7]. The PERK arm of the ER stress sensors is activated within $3 \mathrm{~h}$ after its exposure to heme in human aortic smooth muscle cells, which might lead to their apoptosis [120].

It is important to note that there are few recent studies that explain the direct relationship between ER stress and ICH with specific inhibitors targeting ER transducers. In one study, the secondary brain injury post ICH was shown to increase the protein levels of p-eIF2 $\alpha$ and ATF4 ultimately leading to proapoptotic neuronal cell death. Using a PERK antagonist (GSK2606414) and a selective inhibitor of eIF $2 \alpha$ dephosphorylation, it was shown that neuronal apoptosis is reduced following ICH. PERK inhibition by GSK260414 also resulted in the decrease of CHOP and cleaved caspase-12. Although the study relates PERK signaling pathway inhibition with $\mathrm{ICH}$, the authors have emphasized to have a closer look into the role of PERK and its interaction with the enzymatic activity of calcineurin. As calcium overload in the cytoplasm is also said to be a possible factor for apoptosis, which is induced by calcineurin. By understanding the interrelationship between calcineurin and PERK signaling pathway we shall have a clear insight into the mechanism of neuronal apoptosis post-ICH [121].

Post-ICH, SBI events overrun the inflammatory response, leading to neuroinflammation. This process might significantly increase the activity of other ER stress sensors. The neuroprotective effect of DiDang Tang (DDT; a Chinese traditional medical formula) was clarified in neuronal cells and rats. DDT was shown to mediate through blocking of GRP78-IRE1/PERK pathway. The study confirms that DDT exerted a neuroprotective effect when it is pretreated in the neuronal cells and the pretreated cells showed less ER stress, $\mathrm{Ca}^{2+}$ overload and mitochondrial apoptosis. In addition to the role of PERK and ATF6 involvement in ICH as stated in the aforementioned two studies, this study clarified the role of the inhibition of evolutionarily conserved ER stress sensor, IRE1, and its neuroprotective effect in rats and the neuronal cell model of ICH [122]. One other study explained the role of ATF6 in ICH. Post-ICH, there is an increase in the expression of ATF6 and suppression of ATF6 with melatonin is shown to decrease the brain injury and enhance the neurological functions. The study also explained the decrease in apoptotic neuronal cells were through ATF6 inhibition, which resulted in the reduction of $\mathrm{CHOP}, \mathrm{Bcl}-2$-associated X protein (Bax), and cleaved caspase-3. Furthermore, inhibition of CHOP signaling by siRNA has been shown the proapoptotic nature of ATF6 [123]. 


\section{Conclusions}

Although the pathophysiological symptoms of ICH are known to begin with PBI, SBI plays an important role in the injury mechanism. Various stresses have been shown to contribute to SBI, and all stress factors, from oxidative stress to ER stress, directly or indirectly increase the severity of SBI. ER stress, in combination with the oxidative stress and other potential causes of damage in the injury site, including resident microglia and infiltrating macrophages, contribute to a delay in the healing process. We believe that narrowing down possible therapeutic targets by analyzing each and every factor with evidence-based research is the only way to arrive at a precise therapeutic approach. In this review, we tried to elucidate the pivotal role of ER stress after SBI by considering various cell death pathways that can be induced after prolonged ER stress in ICH. Furthermore, elucidating a role for ER transducers, which may be potential effectors of various cell death pathways in $\mathrm{ICH}$, apart from the traditional process of autophagy, apoptosis, and necrosis, represent added information in this review.

As far as ICH is concerned, research has started to shed light on the concept of cell death mechanisms and possible components that might serve to restore homeostasis; of these, ER stress is crucial. Future studies should address the downstream aspects of ER stress components and their implications in both PBI and SBI.

Author Contributions: S.I.M.T. and S.-T.T. contributed equally to this work. H.-K.L. conceived and supervised the project. S.I.M.T. and S.-T.T. reviewed the literature and drafted the manuscript. H.-Y.H. prepared the figures and drafted the manuscript. W.-F.H. prepared the figures and helped in literature searches. C.-Y.P. and S.-Y.C. critically reviewed the manuscript. All authors have read and agreed to the published version of the manuscript.

Funding: This study was supported by TCMMP 105-06-01 (107), MOST grant 108-2314-B-303-007- and TCRD 108-56.

Conflicts of Interest: The authors declare no conflict of interest.

\section{References}

1. Xi, G.; Keep, R.F.; Hoff, J.T. Mechanisms of brain injury after intracerebral haemorrhage. Lancet Neurol. 2006, 5, 53-63. [CrossRef]

2. An, S.J.; Kim, T.J.; Yoon, B.W. Epidemiology, risk factors, and clinical features of intracerebral hemorrhage: An update. J. Stroke 2017, 19, 3-10. [CrossRef] [PubMed]

3. Hsieh, F.I.; Chiou, H.Y. Stroke: Morbidity, risk factors, and care in Taiwan. J. Stroke 2014, 16, 59-64. [CrossRef] [PubMed]

4. Powers, W.J. Intracerebral hemorrhage and head trauma: Common effects and common mechanisms of injury. Stroke 2010, 41, S107-S110. [CrossRef] [PubMed]

5. Keep, R.F.; Hua, Y.; Xi, G. Intracerebral haemorrhage: Mechanisms of injury and therapeutic targets. Lancet Neurol. 2012, 11, 720-731. [CrossRef]

6. Duan, X.; Wen, Z.; Shen, H.; Shen, M.; Chen, G. Intracerebral hemorrhage, oxidative stress, and antioxidant therapy. Oxid. Med. Cell. Longev. 2016, 2016, 1203285. [CrossRef] [PubMed]

7. Aronowski, J.; Zhao, X. Molecular pathophysiology of cerebral hemorrhage: Secondary brain injury. Stroke 2011, 42, 1781-1786. [CrossRef]

8. Xi, G.; Wagner, K.R.; Keep, R.F.; Hua, Y.; de Courten-Myers, G.M.; Broderick, J.P.; Brott, T.G.; Hoff, J.T. Role of blood clot formation on early edema development after experimental intracerebral hemorrhage. Stroke 1998, 29, 2580-2586. [CrossRef]

9. Wang, W.Y.; Tan, M.S.; Yu, J.T.; Tan, L. Role of pro-inflammatory cytokines released from microglia in Alzheimer's disease. Ann. Transl. Med. 2015, 3, 136. [CrossRef]

10. Wang, J. Preclinical and clinical research on inflammation after intracerebral hemorrhage. Prog. Neurobiol. 2010, 92, 463-477. [CrossRef]

11. Bulters, D.; Gaastra, B.; Zolnourian, A.; Alexander, S.; Ren, D.; Blackburn, S.L.; Borsody, M.; Dore, S.; Galea, J.; Iihara, K.; et al. Haemoglobin scavenging in intracranial bleeding: biology and clinical implications. Nat. Rev. Neurol. 2018, 14, 416-432. [CrossRef] [PubMed]

12. Hua, Y.; Keep, R.F.; Hoff, J.T.; Xi, G. Brain injury after intracerebral hemorrhage: The role of thrombin and iron. Stroke 2007, 38, 759-762. [CrossRef] [PubMed] 
13. Rodrigues, M.A.; Samarasekera, N.; Lerpiniere, C.; Humphreys, C.; McCarron, M.O.; White, P.M.; Nicoll, J.A.R.; Sudlow, C.L.M.; Cordonnier, C.; Wardlaw, J.M.; et al. The Edinburgh CT and genetic diagnostic criteria for lobar intracerebral haemorrhage associated with cerebral amyloid angiopathy: Model development and diagnostic test accuracy study. Lancet Neurol. 2018, 17, 232-240. [CrossRef]

14. Wada, R.; Aviv, R.I.; Fox, A.J.; Sahlas, D.J.; Gladstone, D.J.; Tomlinson, G.; Symons, S.P. CT angiography “spot sign" predicts hematoma expansion in acute intracerebral hemorrhage. Stroke 2007, 38, 1257-1262. [CrossRef] [PubMed]

15. Orito, K.; Hirohata, M.; Nakamura, Y.; Takeshige, N.; Aoki, T.; Hattori, G.; Sakata, K.; Abe, T.; Uchiyama, Y.; Sakamoto, T.; et al. Leakage sign for primary intracerebral hemorrhage: a novel predictor of hematoma growth. Stroke 2016, 47, 958-963. [CrossRef]

16. Hemphill, J.C., III; Bonovich, D.C.; Besmertis, L.; Manley, G.T.; Johnston, S.C. The ICH score: A simple, reliable grading scale for intracerebral hemorrhage. Stroke 2001, 32, 891-897. [CrossRef]

17. Cordonnier, C.; Demchuk, A.; Ziai, W.; Anderson, C.S. Intracerebral haemorrhage: current approaches to acute management. Lancet 2018, 392, 1257-1268. [CrossRef]

18. Matsushita, K.; Meng, W.; Wang, X.; Asahi, M.; Asahi, K.; Moskowitz, M.A.; Lo, E.H. Evidence for apoptosis after intercerebral hemorrhage in rat striatum. J. Cereb. Blood Flow Metab. 2000, 20, 396-404. [CrossRef]

19. Qureshi, A.I.; Suri, M.F.K.; Ostrow, P.T.; Kim, S.H.; Ali, Z.; Shatla, A.A.; Guterman, L.R.; Hopkins, L.N. Apoptosis as a form of cell death in intracerebral hemorrhage. Neurosurgery 2003, 52, 1041-1048. [CrossRef]

20. Burtnick, L.D.; Wong, M.K.C. Interaction of iodoacetamidofluorescein-labelled tropomyosin with deoxyribonuclease I. Fed. Eur. Biochem. Soc. 1989, 244, 319-322. [CrossRef]

21. Son, S.M.; Byun, J.; Roh, S.E.; Kim, S.J.; Mook-Jung, I. Reduced IRE1 $\alpha$ mediates apoptotic cell death by disrupting calcium homeostasis via the InsP3 receptor. Cell Death Dis. 2014, 5, e1188. [CrossRef] [PubMed]

22. Frank, D.; Vince, J.E. Pyroptosis versus necroptosis: Similarities, differences, and crosstalk. Cell Death Differ. 2019, 26, 99-114. [CrossRef] [PubMed]

23. Majmundar, N.; Kim, B.; Prestigiacomo, C.J. Necroptosis pathway in treatment of intracerebral hemorrhage: Novel therapeutic target. World Neurosurg. 2016, 89, 716-717. [CrossRef]

24. Dhuriya, Y.K.; Sharma, D. Necroptosis: a regulated inflammatory mode of cell death. J. Neuroinflamm. 2018, 15. [CrossRef] [PubMed]

25. Zille, M.; Karuppagounder, S.S.; Chen, Y.; Gough, P.J.; Bertin, J.; Finger, J.; Milner, T.A.; Jonas, E.A.; Ratan, R.R. Neuronal death after hemorrhagic stroke In Vitro and In Vivo shares features of ferroptosis and necroptosis. Stroke 2017, 48, 1033-1043. [CrossRef] [PubMed]

26. He, Y.; Wan, S.; Hua, Y.; Keep, R.F.; Xi, G. Autophagy after experimental intracerebral hemorrhage. J. Cereb. Blood Flow Metab. 2007, 28, 897-905. [CrossRef]

27. Bobinger, T.; Burkardt, P.; B. Huttner, H.; Manaenko, A. Programmed cell death after intracerebral hemorrhage. Curr. Neuropharmacol. 2018, 16, 1267-1281. [CrossRef]

28. Fink, S.L.; Cookson, B.T. Caspase-1-dependent pore formation during pyroptosis leads to osmotic lysis of infected host macrophages. Cell. Microbiol. 2006, 8, 1812-1825. [CrossRef]

29. Zhao, H.; Chen, Y.; Feng, H. P2X7 receptor-associated programmed cell death in the pathophysiology of hemorrhagic stroke. Curr. Neuropharmacol. 2018, 16, 1282-1295. [CrossRef]

30. Lin, X.; Ye, H.; Siaw-Debrah, F.; Pan, S.; He, Z.; Ni, H.; Xu, Z.; Jin, K.; Zhuge, Q.; Huang, L. AC-YVAD-CMK inhibits pyroptosis and improves functional outcome after intracerebral hemorrhage. Biomed. Res. Int. 2018, 2018, 3706047. [CrossRef]

31. Li, Q.; Han, X.; Lan, X.; Gao, Y.; Wan, J.; Durham, F.; Cheng, T.; Yang, J.; Wang, Z.; Jiang, C.; et al. Inhibition of neuronal ferroptosis protects hemorrhagic brain. JCI Insight 2017, 2. [CrossRef] [PubMed]

32. Wan, J.; Ren, H.; Wang, J. Iron toxicity, lipid peroxidation and ferroptosis after intracerebral haemorrhage. Stroke Vasc. Neurol. 2019, 4, 93-95. [CrossRef] [PubMed]

33. Westrate, L.M.; Lee, J.E.; Prinz, W.A.; Voeltz, G.K. Form follows function: The importance of endoplasmic reticulum shape. Annu. Rev. Biochem. 2015, 84, 791-811. [CrossRef] [PubMed]

34. Saibil, H. Chaperone machines for protein folding, unfolding and disaggregation. Nat. Rev. Mol. Cell Biol. 2013, 14, 630-642. [CrossRef] [PubMed]

35. Schonthal, A.H. Endoplasmic reticulum stress: Its role in disease and novel prospects for therapy. Science 2012, 2012, 857516. [CrossRef] 
36. Kim, I.; Xu, W.; Reed, J.C. Cell death and endoplasmic reticulum stress: Disease relevance and therapeutic opportunities. Nat. Rev. Drug Discov. 2008, 7, 1013-1030. [CrossRef]

37. Smith, H.L.; Mallucci, G.R. The unfolded protein response: Mechanisms and therapy of neurodegeneration. Brain 2016, 139, 2113-2121. [CrossRef]

38. Yoshida, H. ER stress and diseases. FEBS J. 2007, 274, 630-658. [CrossRef]

39. Chen, Y.; Brandizzi, F. IRE1: ER stress sensor and cell fate executor. Trends Cell Biol. 2013, 23, 547-555. [CrossRef]

40. Merksamer, P.I.; Papa, F.R. The UPR and cell fate at a glance. J. Cell Sci. 2010, 123, 1003-1006. [CrossRef]

41. Karagoz, G.E.; Acosta-Alvear, D.; Nguyen, H.T.; Lee, C.P.; Chu, F.; Walter, P. An unfolded protein-induced conformational switch activates mammalian IRE1. eLife 2017, 6. [CrossRef] [PubMed]

42. Gardner, B.M.; Walter, P. Unfolded proteins are Ire1-activating ligands that directly induce the unfolded protein response. Science 2011, 333, 1891-1894. [CrossRef] [PubMed]

43. Adams, C.J.; Kopp, M.C.; Larburu, N.; Nowak, P.R.; Ali, M.M.U. Structure and molecular mechanism of er stress signaling by the unfolded protein response signal activator IRE1. Front. Mol. Biosci. 2019, 6, 11. [CrossRef] [PubMed]

44. Amin-Wetzel, N.; Saunders, R.A.; Kamphuis, M.J.; Rato, C.; Preissler, S.; Harding, H.P.; Ron, D. a J-protein co-chaperone recruits BiP to monomerize IRE1 and repress the unfolded protein response. Cell 2017, 171, $1625-1637$. [CrossRef]

45. Hetz, C.; Papa, F.R. The unfolded protein response and cell fate control. Mol. Cell 2018, 69, 169-181. [CrossRef]

46. Calfon, M.; Zeng, H.; Urano, F.; Till, J.H.; Hubbard, S.R.; Harding, H.P.; Clark, S.G.; Ron, D. IRE1 couples endoplasmic reticulum load to secretory capacity by processing the XBP-1 mRNA. Nature 2002, 415, 92-96. [CrossRef] [PubMed]

47. Hollien, J.; Lin, J.H.; Li, H.; Stevens, N.; Walter, P.; Weissman, J.S. Regulated Ire1-dependent decay of messenger RNAs in mammalian cells. J. Cell Biol. 2009, 186, 323-331. [CrossRef] [PubMed]

48. Maurel, M.; Chevet, E.; Tavernier, J.; Gerlo, S. Getting RIDD of RNA: IRE1 in cell fate regulation. Trends Biochem. Sci. 2014, 39, 245-254. [CrossRef] [PubMed]

49. Hillary, R.F.; FitzGerald, U. a lifetime of stress: ATF6 in development and homeostasis. J. Biomed. Sci. 2018, 25, 48. [CrossRef]

50. Ye, J.; Rawson, R.B.; Komuro, R.; Chen, X.; Dave, U.P.; Prywes, R.; Brown, M.S.; Goldstein, J.L. ER stress induces cleavage of membrane-bound ATF6 by the same proteases that process SREBPs. Mol. Cell 2000, 6, 1355-1364. [CrossRef]

51. Li, M.; Baumeister, P.; Roy, B.; Phan, T.; Foti, D.; Luo, S.; Lee, A.S. ATF6 as a transcription activator of the endoplasmic reticulum stress element: Thapsigargin stress-induced changes and synergistic interactions with NF-Y and YY1. Mol. Cell. Biol. 2000, 20, 5096-5106. [CrossRef] [PubMed]

52. Thuerauf, D.J.; Marcinko, M.; Belmont, P.J.; Glembotski, C.C. Effects of the isoform-specific characteristics of ATF6 $\alpha$ and ATF6 $\beta$ on endoplasmic reticulum stress response gene expression and cell viability. J. Biol. Chem. 2007, 282, 22865-22878. [CrossRef] [PubMed]

53. Szegezdi, E.; Logue, S.E.; Gorman, A.M.; Samali, A. Mediators of endoplasmic reticulum stress-induced apoptosis. EMBO Rep. 2006, 7, 880-885. [CrossRef] [PubMed]

54. Walter, F.; O’Brien, A.; Concannon, C.G.; Dussmann, H.; Prehn, J.H.M. ER stress signaling has an activating transcription factor $6 \alpha$ (ATF6)-dependent "off-switch". J. Biol. Chem. 2018, 293, 18270-18284. [CrossRef] [PubMed]

55. Harding, H.P.; Zhang, Y.; Ron, D. Protein translation and folding are coupled by an endoplasmic-reticulum-resident kinase. Nature 1999, 397, 271-274. [CrossRef]

56. Bertolotti, A.; Zhang, Y.; Hendershot, L.M.; Harding, H.P.; Ron, D. Dynamic interaction of BiP and ER stress transducers in the unfolded-protein response. Nat. Cell Biol. 2000, 2, 326-332. [CrossRef]

57. Mori, K. Tripartite management of unfolded proteins in the endoplasmic reticulum. Cell 2000, 101, 451-454. [CrossRef]

58. Harding, H.P.; Zhang, Y.; Bertolotti, A.; Zeng, H.; Ron, D. Perk is essential for translational regulation and cell survival during the unfolded protein response. Mol. Cell 2000, 5, 897-904. [CrossRef]

59. Wang, P.; Li, J.; Tao, J.; Sha, B. The luminal domain of the ER stress sensor protein PERK binds misfolded proteins and thereby triggers PERK oligomerization. J. Biol. Chem. 2018, 293, 4110-4121. [CrossRef] 
60. Novoa, I.; Zeng, H.; Harding, H.P.; Ron, D. Feedback inhibition of the unfolded protein response by GADD34-mediated dephosphorylation of eIF2 $\alpha$. J. Cell Biol. 2001, 153, 1011-1022. [CrossRef]

61. Walter, P.; Ron, D. The unfolded protein response: from stress pathway to homeostatic regulation. Science 2011, 334, 1081-1086. [CrossRef] [PubMed]

62. Mekahli, D.; Bultynck, G.; Parys, J.B.; De Smedt, H.; Missiaen, L. Endoplasmic-Reticulum calcium depletion and disease. Cold Spring Harb. Perspect. Biol. 2011, 3. [CrossRef] [PubMed]

63. Foskett, J.K.; White, C.; Cheung, K.H.; Mak, D.O. Inositol trisphosphate receptor $\mathrm{Ca}^{2+}$ release channels. Physiol. Rev. 2007, 87, 593-658. [CrossRef] [PubMed]

64. Zalk, R.; Lehnart, S.E.; Marks, A.R. Modulation of the ryanodine receptor and intracellular calcium. Annu. Rev. Biochem. 2007, 76, 367-385. [CrossRef]

65. Santulli, G.; Nakashima, R.; Yuan, Q.; Marks, A.R. Intracellular calcium release channels: An update. J. Physiol. 2017, 595, 3041-3051. [CrossRef]

66. Chang, W.C. Store-Operated calcium channels and pro-inflammatory signals. Acta Pharm. Sin. 2006, $27,813-820$. [CrossRef]

67. Smyth, J.T.; Hwang, S.Y.; Tomita, T.; DeHaven, W.I.; Mercer, J.C.; Putney, J.W. Activation and regulation of store-operated calcium entry. J. Cell. Mol. Med. 2010, 14, 2337-2349. [CrossRef]

68. Gaut, J.R.; Hendershot, L.M. The modification and assembly of proteins in the endoplasmic reticulum. Curr. Opin. Cell Biol. 1993, 5, 589-595. [CrossRef]

69. Xu, C.; Bailly-Maitre, B.; Reed, J.C. Endoplasmic reticulum stress: Cell life and death decisions. J. Clin. Invest. 2005, 115, 2656-2664. [CrossRef]

70. Kuznetsov, G.; Brostrom, M.A.; Brostrom, C.O. Demonstration of a calcium requirement for secretory protein processing and export. Differential effects of calcium and dithiothreitol. J. Biol. Chem. 1992, 267, 3932-3939.

71. Lodish, H.F.; Kong, N.; Wikstrom, L. Calcium is required for folding of newly made subunits of the asialoglycoprotein receptor within the endoplasmic reticulum. J. Biol. Chem. 1992, 267, 12753-12760. [PubMed]

72. Ma, Y.; Hendershot, L.M. ER chaperone functions during normal and stress conditions. J. Chem. Neuroanat. 2004, 28, 51-65. [CrossRef] [PubMed]

73. Secondo, A.; Petrozziello, T.; Tedeschi, V.; Boscia, F.; Vinciguerra, A.; Ciccone, R.; Pannaccione, A.; Molinaro, P.; Pignataro, G.; Annunziato, L. ORAI1/STIM1 interaction intervenes in stroke and in neuroprotection induced by ischemic preconditioning through store-operated calcium entry. Stroke 2019, 50, 1240-1249. [CrossRef] [PubMed]

74. Troupes, C.D.; Wallner, M.; Borghetti, G.; Zhang, C.; Mohsin, S.; von Lewinski, D.; Berretta, R.M.; Kubo, H.; Chen, X.; Soboloff, J.; et al. Role of STIM1 (stromal interaction molecule 1) in hypertrophy-related contractile dysfunction. Circ. Res. 2017, 121, 125-136. [CrossRef]

75. Benard, L.; Oh, J.G.; Cacheux, M.; Lee, A.; Nonnenmacher, M.; Matasic, D.S.; Kohlbrenner, E.; Kho, C.; Pavoine, C.; Hajjar, R.J.; et al. Cardiac Stim1 silencing impairs adaptive hypertrophy and promotes heart failure through inactivation of mTORC2/Akt signaling. Circulation 2016, 133, 1458-1471. [CrossRef]

76. Braun, A.; Varga-Szabo, D.; Kleinschnitz, C.; Pleines, I.; Bender, M.; Austinat, M.; Bosl, M.; Stoll, G.; Nieswandt, B. Orai1 (CRACM1) is the platelet SOC channel and essential for pathological thrombus formation. Blood 2009, 113, 2056-2063. [CrossRef]

77. Ahmad, F.; Boulaftali, Y.; Greene, T.K.; Ouellette, T.D.; Poncz, M.; Feske, S.; Bergmeier, W. Relative contributions of stromal interaction molecule 1 and CalDAG-GEFI to calcium-dependent platelet activation and thrombosis. J. Thromb. Haemost. 2011, 9, 2077-2086. [CrossRef]

78. Berna-Erro, A.; Braun, A.; Kraft, R.; Kleinschnitz, C.; Schuhmann, M.K.; Stegner, D.; Wultsch, T.; Eilers, J.; Meuth, S.G.; Stoll, G.; et al. STIM2 regulates capacitive $\mathrm{Ca}^{2+}$ entry in neurons and plays a key role in hypoxic neuronal cell death. Sci. Signal. 2009, 2, ra67. [CrossRef]

79. Niu, M.; Dai, X.; Zou, W.; Yu, X.; Teng, W.; Chen, Q.; Sun, X.; Yu, W.; Ma, H.; Liu, P. Autophagy, endoplasmic reticulum stress and the unfolded protein response in intracerebral hemorrhage. Transl. Neurosci. 2017, 8, 37-48. [CrossRef]

80. Nakka, V.P.; Prakash-Babu, P.; Vemuganti, R. Crosstalk between endoplasmic reticulum stress, oxidative stress, and autophagy: Potential therapeutic targets for acute CNS injuries. Mol. Neurobiol. 2016, 53, 532-544. [CrossRef] 
81. He, Z.; Ostrowski, R.P.; Sun, X.; Ma, Q.; Huang, B.; Zhan, Y.; Zhang, J.H. CHOP silencing reduces acute brain injury in the rat model of subarachnoid hemorrhage. Stroke 2012, 43, 484-490. [CrossRef] [PubMed]

82. Liew, H.K.; Hu, W.F.; Lin, P.B.; Wang, P.K.; Tsai, A.P.; Pang, C.Y.; Chen, T.Y. Over-Activated proteasome mediates neuroinflammation on acute intracerebral hemorrhage in rats. Cells 2019, 8, 1326. [CrossRef] [PubMed]

83. Guo, M.L.; Liao, K.; Periyasamy, P.; Yang, L.; Cai, Y.; Callen, S.E.; Buch, S. Cocaine-Mediated microglial activation involves the ER stress-autophagy axis. Autophagy 2015, 11, 995-1009. [CrossRef] [PubMed]

84. Burgos-Moron, E.; Abad-Jimenez, Z.; Maranon, A.M.; Iannantuoni, F.; Escribano-Lopez, I.; Lopez-Domenech, S.; Salom, C.; Jover, A.; Mora, V.; Roldan, I.; et al. Relationship between oxidative stress, ER stress, and inflammation in type 2 diabetes: The battle continues. J. Clin. Med. 2019, 8, 1385. [CrossRef] [PubMed]

85. Pintado, C.; Macias, S.; Dominguez-Martin, H.; Castano, A.; Ruano, D. Neuroinflammation alters cellular proteostasis by producing endoplasmic reticulum stress, autophagy activation and disrupting ERAD activation. Sci. Rep. 2017, 7, 8100. [CrossRef]

86. Demay, Y.; Perochon, J.; Szuplewski, S.; Mignotte, B.; Gaumer, S. The PERK pathway independently triggers apoptosis and a Rac1/Slpr/JNK/Dilp8 signaling favoring tissue homeostasis in a chronic ER stress Drosophila model. Cell Death Dis. 2014, 5, e1452. [CrossRef]

87. Adler, H.T.; Chinery, R.; Wu, D.Y.; Kussick, S.J.; Payne, J.M.; Fornace, A.J., Jr.; Tkachuk, D.C. Leukemic HRX fusion proteins inhibit GADD34-induced apoptosis and associate with the GADD34 and hSNF5/INI1 proteins. Mol. Cell. Biol. 1999, 19, 7050-7060. [CrossRef]

88. Morishima, N.; Nakanishi, K.; Nakano, A. Activating transcription factor-6 (ATF6) mediates apoptosis with reduction of myeloid cell leukemia sequence 1 (Mcl-1) protein via induction of WW domain binding protein 1. J. Biol. Chem. 2011, 286, 35227-35235. [CrossRef]

89. Xiong, Y.; Chen, H.; Lin, P.; Wang, A.; Wang, L.; Jin, Y. ATF6 knockdown decreases apoptosis, arrests the S phase of the cell cycle, and increases steroid hormone production in mouse granulosa cells. Am. J. Physiol. Cell Physiol. 2017, 312, C341-C353. [CrossRef]

90. Eftink, M.R.; Chiron, C.A. Fluorescence quenching studies with proteins. Anal. Biochem. 1981, 114, $199-227$. [CrossRef]

91. Nishitoh, H.; Saitoh, M.; Mochida, Y.; Takeda, K.; Nakano, H.; Rothe, M.; Miyazono, K.; Ichijo, H. ASK1 is essential for JNK/SAPK activation by TRAF2. Mol. Cell 1998, 2, 389-395. [CrossRef]

92. Harada, C.; Nakamura, K.; Namekata, K.; Okumura, A.; Mitamura, Y.; Iizuka, Y.; Kashiwagi, K.; Yoshida, K.; Ohno, S.; Matsuzawa, A.; et al. Role of apoptosis signal-regulating kinase 1 in stress-induced neural cell apoptosis In Vivo. Am. J. Pathol. 2006, 168, 261-269. [CrossRef] [PubMed]

93. Hatai, T.; Matsuzawa, A.; Inoshita, S.; Mochida, Y.; Kuroda, T.; Sakamaki, K.; Kuida, K.; Yonehara, S.; Ichijo, H.; Takeda, K. Execution of apoptosis signal-regulating kinase 1 (ASK1)-induced apoptosis by the mitochondria-dependent caspase activation. J. Biol. Chem. 2000, 275, 26576-26581. [CrossRef] [PubMed]

94. Maundrell, K.; Antonsson, B.; Magnenat, E.; Camps, M.; Muda, M.; Chabert, C.; Gillieron, C.; Boschert, U.; Vial-Knecht, E.; Martinou, J.C.; et al. Bcl-2 undergoes phosphorylation by c-Jun N-terminal kinase/stress-activated protein kinases in the presence of the constitutively active GTP-binding protein Rac1. J. Biol. Chem. 1997, 272, 25238-25242. [CrossRef] [PubMed]

95. Yamamoto, K.; Ichijo, H.; Korsmeyer, S.J. BCL-2 is phosphorylated and inactivated by an ASK1/Jun N-terminal protein kinase pathway normally activated at G(2)/M. Mol. Cell. Biol. 1999, 19, 8469-8478. [CrossRef] [PubMed]

96. Deegan, S.; Saveljeva, S.; Gorman, A.M.; Samali, A. Stress-Induced self-cannibalism: On the regulation of autophagy by endoplasmic reticulum stress. Cell. Mol. Life Sci. 2013, 70, 2425-2441. [CrossRef] [PubMed]

97. Rzymski, T.; Milani, M.; Pike, L.; Buffa, F.; Mellor, H.R.; Winchester, L.; Pires, I.; Hammond, E.; Ragoussis, I.; Harris, A.L. Regulation of autophagy by ATF4 in response to severe hypoxia. Oncogene 2010, 29, 4424-4435. [CrossRef]

98. Rouschop, K.M.; van den Beucken, T.; Dubois, L.; Niessen, H.; Bussink, J.; Savelkouls, K.; Keulers, T.; Mujcic, H.; Landuyt, W.; Voncken, J.W.; et al. The unfolded protein response protects human tumor cells during hypoxia through regulation of the autophagy genes MAP1LC3B and ATG5. J. Clin. Invest. 2010, 120, 127-141. [CrossRef] 
99. B'Chir, W.; Maurin, A.C.; Carraro, V.; Averous, J.; Jousse, C.; Muranishi, Y.; Parry, L.; Stepien, G.; Fafournoux, P.; Bruhat, A. The eIF2 $\alpha /$ ATF4 pathway is essential for stress-induced autophagy gene expression. Nucleic Acids Res. 2013, 41, 7683-7699. [CrossRef]

100. Rashid, H.O.; Yadav, R.K.; Kim, H.R.; Chae, H.J. ER stress: Autophagy induction, inhibition and selection. Autophagy 2015, 11, 1956-1977. [CrossRef]

101. Yanagisawa, S.; Katoh, H.; Imai, T.; Nomura, S.; Watanabe, M. The relationship between inflammasomes and the endoplasmic reticulum stress response in the injured spinal cord. Neurosci. Lett. 2019, 705, 54-59. [CrossRef] [PubMed]

102. Shin, S.; Argon, Y. Stressed-Out endoplasmic reticulum inflames the mitochondria. Immunity 2015, 43, 409-411. [CrossRef] [PubMed]

103. Zhou, R.; Tardivel, A.; Thorens, B.; Choi, I.; Tschopp, J. Thioredoxin-Interacting protein links oxidative stress to inflammasome activation. Nat. Immunol. 2010, 11, 136-140. [CrossRef] [PubMed]

104. Oslowski, C.M.; Hara, T.; O’Sullivan-Murphy, B.; Kanekura, K.; Lu, S.; Hara, M.; Ishigaki, S.; Zhu, L.J.; Hayashi, E.; Hui, S.T.; et al. Thioredoxin-Interacting protein mediates ER stress-induced beta cell death through initiation of the inflammasome. Cell Metab. 2012, 16, 265-273. [CrossRef]

105. Lebeaupin, C.; Proics, E.; de Bieville, C.H.; Rousseau, D.; Bonnafous, S.; Patouraux, S.; Adam, G.; Lavallard, V.J.; Rovere, C.; Le Thuc, O.; et al. ER stress induces NLRP3 inflammasome activation and hepatocyte death. Cell Death Dis. 2015, 6, e1879. [CrossRef]

106. Yang, J.-R.; Yao, F.-H.; Zhang, J.-G.; Ji, Z.-Y.; Li, K.-L.; Zhan, J.; Tong, Y.-N.; Lin, L.-R.; He, Y.-N. Ischemia-Reperfusion induces renal tubule pyroptosis via the CHOP-caspase-11 pathway. Am. J. Physiol. Ren. Physiol. 2014, 306, F75-F84. [CrossRef]

107. Zhang, J.; Zhang, K.; Li, Z.; Guo, B. ER Stress-Induced inflammasome activation contributes to hepatic inflammation and steatosis. J. Clin. Cell. Immunol. 2016, 7. [CrossRef]

108. Zhu, P.; Hu, S.; Jin, Q.; Li, D.; Tian, F.; Toan, S.; Li, Y.; Zhou, H.; Chen, Y. Ripk3 promotes ER stress-induced necroptosis in cardiac IR injury: a mechanism involving calcium overload/XO/ROS/mPTP pathway. Redox Biol. 2018, 16, 157-168. [CrossRef]

109. Saveljeva, S.; Mc Laughlin, S.L.; Vandenabeele, P.; Samali, A.; Bertrand, M.J.M. Endoplasmic reticulum stress induces ligand-independent TNFR1-mediated necroptosis in L929 cells. Cell Death Dis. 2015, 6, e1587. [CrossRef]

110. Chen, Y.; Mi, Y.; Zhang, X.; Ma, Q.; Song, Y.; Zhang, L.; Wang, D.; Xing, J.; Hou, B.; Li, H.; et al. Dihydroartemisinin-Induced unfolded protein response feedback attenuates ferroptosis via PERK/ATF4/HSPA5 pathway in glioma cells. J. Exp. Clin. Cancer Res. 2019, 38, 402. [CrossRef]

111. Dixon, S.J.; Patel, D.N.; Welsch, M.; Skouta, R.; Lee, E.D.; Hayano, M.; Thomas, A.G.; Gleason, C.E.; Tatonetti, N.P.; Slusher, B.S.; et al. Pharmacological inhibition of cystine-glutamate exchange induces endoplasmic reticulum stress and ferroptosis. eLife 2014, 3, e02523. [CrossRef] [PubMed]

112. Sen, T.; Saha, P.; Gupta, R.; Foley, L.M.; Jiang, T.; Abakumova, O.S.; Hitchens, T.K.; Sen, N. Aberrant ER stress induced neuronal-IFN $\beta$ elicits white matter injury due to microglial activation and T-cell infiltration after TBI. J. Neurosci. 2020, 40, 424-446. [CrossRef]

113. Liu, Y.; Min, J.W.; Feng, S.; Subedi, K.; Qiao, F.; Mammenga, E.; Callegari, E.; Wang, H. Therapeutic role of a cysteine precursor, OTC, in ischemic stroke is mediated by improved proteostasis in mice. Transl. Stroke Res. 2020, 11, 147-160. [CrossRef]

114. Liu, Y.; Feng, S.; Subedi, K.; Wang, H. Attenuation of ischemic stroke-caused brain injury by a monoamine oxidase inhibitor involves improved proteostasis and reduced neuroinflammation. Mol. Neurobiol. 2020, 57, 937-948. [CrossRef] [PubMed]

115. Sharma, V.; Ounallah-Saad, H.; Chakraborty, D.; Hleihil, M.; Sood, R.; Barrera, I.; Edry, E.; Kolatt Chandran, S.; Ben Tabou de Leon, S.; Kaphzan, H.; et al. Local inhibition of PERK enhances memory and reverses age-related deterioration of cognitive and neuronal properties. J. Neurosci. 2018, 38, 648-658. [CrossRef] [PubMed]

116. Gharibani, P.; Modi, J.; Menzie, J.; Alexandrescu, A.; Ma, Z.; Tao, R.; Prentice, H.; Wu, J.Y. Comparison between single and combined post-treatment with S-Methyl-N,N-diethylthiolcarbamate sulfoxide and taurine following transient focal cerebral ischemia in rat brain. Neuroscience 2015, 300, 460-473. [CrossRef] 
117. Han, Y.; Yi, W.; Qin, J.; Zhao, Y.; Zhang, J.; Chang, X. Carbon monoxide offers neuroprotection from hippocampal cell damage induced by recurrent febrile seizures through the PERK-activated ER stress pathway. Neurosci. Lett. 2015, 585, 126-131. [CrossRef] [PubMed]

118. Rubovitch, V.; Barak, S.; Rachmany, L.; Goldstein, R.B.; Zilberstein, Y.; Pick, C.G. The neuroprotective effect of salubrinal in a mouse model of traumatic brain injury. Neuromol. Med. 2015, 17, 58-70. [CrossRef]

119. Kumar, R.; Azam, S.; Sullivan, J.M.; Owen, C.; Cavener, D.R.; Zhang, P.; Ron, D.; Harding, H.P.; Chen, J.J.; Han, A.; et al. Brain ischemia and reperfusion activates the eukaryotic initiation factor $2 \alpha$ kinase, PERK. J. Neurochem. 2001, 77, 1418-1421. [CrossRef]

120. Gall, T.; Petho, D.; Nagy, A.; Hendrik, Z.; Mehes, G.; Potor, L.; Gram, M.; Akerstrom, B.; Smith, A.; Nagy, P.; et al. Heme induces endoplasmic reticulum stress (HIER stress) in human aortic smooth muscle cells. Front. Physiol. 2018, 9, 1595. [CrossRef]

121. Meng, C.; Zhang, J.; Dang, B.; Li, H.; Shen, H.; Li, X.; Wang, Z. PERK Pathway activation promotes intracerebral hemorrhage induced secondary brain injury by inducing neuronal apoptosis both In Vivo and In Vitro. Front. Neurosci. 2018, 12, 111. [CrossRef]

122. Xu, W.; Lu, X.; Zheng, J.; Li, T.; Gao, L.; Lenahan, C.; Shao, A.; Zhang, J.; Yu, J. Melatonin protects against neuronal apoptosis via suppression of the ATF6/CHOP pathway in a rat model of intracerebral hemorrhage. Front. Neurosci. 2018, 12, 638. [CrossRef]

123. Huang, Q.; Lan, T.; Lu, J.; Zhang, H.; Zhang, D.; Lou, T.; Xu, P.; Ren, J.; Zhao, D.; Sun, L.; et al. DiDang tang inhibits endoplasmic reticulum stress-mediated apoptosis induced by oxygen glucose deprivation and intracerebral hemorrhage through blockade of the GRP78-IRE1/PERK pathways. Front. Pharm. 2018, 9, 1423. [CrossRef]

(C) 2020 by the authors. Licensee MDPI, Basel, Switzerland. This article is an open access article distributed under the terms and conditions of the Creative Commons Attribution (CC BY) license (http://creativecommons.org/licenses/by/4.0/). 